including incidentally an excellent account of the toxicology of dinitro-ortho-cresol. Once the reader has mastered this different approach he will find that the authors have considered many aspects of industrial toxicology from the essential angle of their biochemical origin, an approach which must surely form the fundamental basis of this subject in future. At present there is just sufficient knowledge for a start to be made and the authors have carried out their difficult enterprise extremely well.

\section{XIIth International Congress on Occupational Health}

The XIIth International Congress on Occupational Health will be held in Helsinki from July 1 to 6, 1957.

The preliminary programme is divided into (1) Congress subjects, (2) section subjects, (3) reviews, (4) round table, and (5) group meetings. The Congress subjects are industrial noise, evaluation of invalidity, industrial hygiene norms, and cardiacs and work.

There will be an opportunity before and after the Congress for members to visit and acquaint themselves with the organization and operation of occupational medicine and hygiene in other Scandinavian countries. There will be an excursion on July 7 to industrial establishments and hospitals in various parts of Finland.

The official languages of the Congress are English, French, German and Spanish.

The Nicolo Castellino prize, value 3,000,000 lire, will be awarded for the first time at the Congress at Helsinki. The award will be made for what, in the opinion of the assessors, is adjudged to be the most outstanding investigation in the field of occupational health by a research worker, who must be under the age of 35 years and is not the holder of a university chair. Details of the competition will be published at an early date by the Directors of the Fund or can be obtained direct from Directors of Nicolo Castellino Prize, The University, Naples, Italy.

A film competition will be organized in connexion with the Congress.

The Congress fee for members is $£ 58 \mathrm{~s}$. and for associate members $£ 312 \mathrm{~s}$.

Persons who wish to present original scientific papers should state the title of the paper, together with a summary of not more than 200 words in English and French, and should reach the Committee not later than March 1, 1957.

The final detailed programme and application forms will be posted early in 1957. Notification of intention to be present must be made by May 1, 1957. Hotel accommodation cannot be guaranteed after that date.

Further information relating to the Congress may be had on application to the Organizing Committee, c/o Työterveyslaitos, Haartmaninkatu 1, Helsinki-Töölö. The Chairman is Dr. Leo Noro and the SecretaryGeneral Dr. Pentti Sumari.

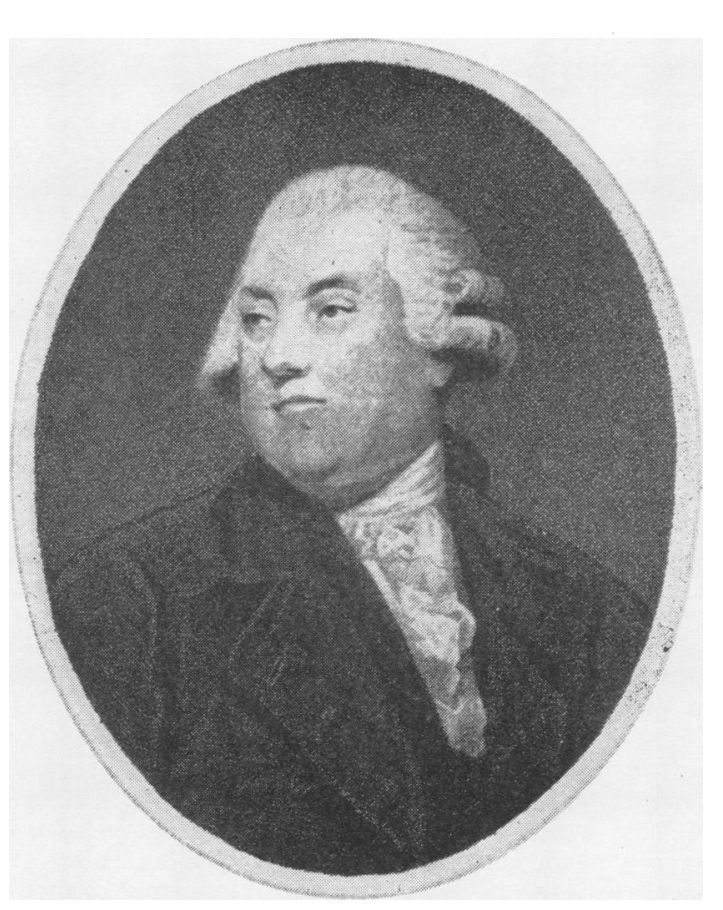

\section{Percivall Pott (1714-1788) and Chimney Sweepers' Cancer of the Scrotum}

\section{JOHN R. BROWN and JOHN L. THORNTON}

From the Department of Applied Physiology, London School of Hygiene and Tropical Medicine, and the Medical College Library, St. Bartholomew's Hospital, London

With the possible exception of John Hunter, Percivall Pott is remembered as the most eminent surgical writer of his period, and the premier position he held in his profession was recognized not only in England but abroad. The fact that he is associated eponymously with several conditions has ensured that his name is still constantly before the medical profession but the facts of his career are little appreciated. Percivall Pott has not been the subject of a full-scale biography, and there are certain divergencies of opinion among those who have written about him. However, the following brief facts outline the activities of one who published the first description of an occupational cancer, and who should be numbered among the pioneers of occupational medicine.

Born in 1714 in Threadneedle Street, London, on the present site of the Bank of England, Percivall Pott was educated with a view to his becoming a clergyman. 
However, on August 1, 1729, he was apprenticed to Edward Nourse (1701-1761), surgeon at St. Bartholomew's Hospital, paying a premium of $£ 210$ for the seven years' apprenticeship. Nourse gave lectures at his house in Aldersgate Street, at Barber-Surgeon's Hall, and possibly at St. Bartholomew's Hospital, and Pott became his prosector. On September 7, 1736, Pott was awarded the Grand Diploma by the Court of Examiners of the Barber Surgeons Company. In 1739 he applied unsuccessfully for the vacant assistant-surgeoncy at St. Bartholomew's Hospital, but on March 7, 1744/5, was appointed to that office. On November 30,1749 , he became full surgeon to the Hospital, occupying that position until he resigned on July 12,1787 . He was then nominated a Governor.

When Percivall Pott's mother died in 1746 he married Sarah Cruttenden, the daughter of a Director of the East India Company, and they had five sons (one died in infancy) and four daughters, one of whom married Sir James Earle. One of his sons, Joseph Holden Pott, became Archdeacon of St. Albans and London, and a great-great-grandson became Archdeacon of Berkshire.

Pott lived successively in Fenchurch Street, Bow Lane, Watling Street, Lincolns Inn Fields, and Prince's Street, Hanover Square. In 1756, while riding down the Old Kent Road to visit the Lock Hospital he was thrown from his horse, whereby he suffered a compound fracture of the ankle. During his convalescence Pott started to write a treatise on ruptures, and it is possible that but for his accident Pott would not have turned to authorship, and surgical literature would have been the poorer. His writings went into numerous editions, and several were translated into foreign languages (Lloyd, 1933; Horder, 1894). A treatise on ruptures and An account of a particular kind of rupture frequently attendant upon new-born children were published in 1756. His other important books include Observations on that disorder of the corner of the eye, commonly called fistula lachrymalis (1758); Observations on the nature and consequences of wounds and contusions of the head (1760), which includes the first description of " Pott's puffy tumour", a circumscribed oedema of the scalp associated with osteomyelitis of the skull; Practical remarks upon the hydrocele or watery rupture (1762); Remarks on the disease, commonly called a fistula in ano (1765); Observations on the nature and consequences of those injuries to which the head is liable from external violence (1768); Some few general remarks upon fractures and dislocations (1768), in which he described "Pott's fracture" (pp. 57-64), Remarks on that kind of palsy of the lower limbs, which is frequently found to accompany a curvature of the spine (1779), his classical description of spinal curvature due to tuberculous caries, although Pott did not recognize its tuberculous nature, which became known as "Pott's disease"; and Further remarks on the useless state of the lower limbs, in consequence of a curvature of the spine (1782).

Several editions of his collected writings were published, and his writings remain of interest today. Pott died on December 22,1788, and his influence on surgery continued to be exerted by his many pupils, among whom were John Hunter and John Abernethy.

Percivall Pott's account of chimney sweepers' cancer has been cited as the first description of an occupational cancer. It was published in 1775 in his Chirurgical observations Relative to the Cataract, the Polypus of the Nose, the Cancer of the Scrotum, [etc.], London. The following is the complete text of the essay.

\section{Cancer Scroti}

" Ramazzini (sic) has written a book de morbis artificum; the Colic of Poictou is a well-known distemper, and every body is acquainted with the disorders to which painters, plummers, glaziers, and the workers in white lead, are liable; but there is a disease as peculiar to a certain set of people, which has not, at least to my knowledge, been publickly noticed; I mean the chimney-sweepers' cancer.

It is a disease which always makes its first attack on, and its first appearance in, the inferior part of the scrotum; where it produces a superficial, painful, ragged, ill-looking sore, with hard and rising edges. The trade call it the soot-wart. I never saw it under the age of puberty, which is, I suppose, one reason, why it is generally taken, both by patient and surgeon, for venereal, and being treated with mercurials, is thereby soon and much exasperated: in no great length of time, it pervades the skin, dartos, and membranes of the scrotum, and seizes the testicle, which it inlarges, hardens, and renders truly and thoroughly distempered; from whence it makes its way up the spermatic process into the abdomen, most frequently indurating, and spoiling the inguinal glands: when arrived within the abdomen, it affects some of the viscera, and then very soon becomes painfully destructive.

The fate of these people seems singularly hard; in their early infancy, they are most frequently treated with great brutality, and almost starved with cold and hunger; they are thrust up narrow, and sometimes hot chimnies, where they are bruised, burned, and almost suffocated; and when they get to puberty, become peculiarly liable to a most noisome, painful, and fatal disease.

Of this last circumstance there is not the least doubt, though perhaps it may not have been sufficiently attended to, to make it generally known. Other people have cancers of the same parts; and so have others, besides lead-workers, the Poictou colic, and the consequent paralysis; but it is nevertheless a disease to which they are peculiarly liable; and so are chimney-sweepers to the cancer of the scrotum and testicles.

If there be any chance of putting a stop to, or preventing this mischief, it must be the immediate removal of the part affected; I mean that part of the scrotum where the sore is, for if it be suffered to remain until the virus has seized the testicle, it is generally too late even for castration. I have many times made the experiment; but though the sores, after such operation, have, in some instances, healed kindly, and the patients have gone from the hospital seemingly well, yet, in the space of a few months, it has generally happened, that they have returned either with the same disease in the other testicle, or in the glands of the groin, or with such wan complexions, such pale, leaden, countenances, such a total loss of strength, and such frequent and acute internal pains, as have sufficiently proved a diseased state of some of the viscera, and which have soon been followed by a painful death.

If extirpation ever bids fair for the cure of a cancer, it seems to be in this case; but then the operation should be immediate, and before the habit is tainted. The disease, in these people, seems to derive its origin from a lodgment of soot in the rugae of the scrotum, and at 
first not to be a disease of the habit. In other cases of a cancerous nature, in which the habit is too frequently concerned, we have not often so fair a prospect of success by the removal of the distempered part; and are obliged to be content with means, which I wish I could say were truly palliative; but here the subjects are young, in general in good health, at least at first; the disease brought on them by their occupation, and in all probability local; which last circumstance may, I think, be fairly presumed from its always seizing the same part: all this makes it (at first) a very different case from a cancer which appears in an elderly man, whose fluids are become acrimonious from time, as well as other causes; or from the same kind of complaint in women who have ceased to menstruate. But be all this as it may, the scrotum is no vital organ, nor can the loss of a part of it ever be attended with any, the smallest degree of inconvenience; and if a life can be preserved by the removal of all that portion that is distempered, it will be a very good and easy composition; for when the disease has got head, it is rapid in its progress, painful in all its attacks, and most certainly destructive in its event."

Pott states that he had not seen a case under the age of puberty, but in the edition of The Chirurgical works of Percivall Pott edited by Sir James Earle, the latter added a footnote (Vol. 3, 1808, p. 178) mentioning that he had encountered a case in St. Bartholomew's Hospital, in a child of 8 who was an apprentice to a chimney sweeper. He had shown the case to Pott, who acknowledged it to be one of cancer of the scrotum. In a further annotation (Ibid., pp. 180-183) Earle mentions that Pott appeared to believe that the disease was peculiar to chimney sweepers, despite the fact that Pott definitely states, "Other people have cancer of the same parts ". Earle relates the case of a gardener who was admitted to St. Bartholomew's Hospital with "a large cancerous sore, which reached from the bend of the wrist to the knuckles, occupying almost the whole of the back of the left hand". The patient had been engaged in scattering soot in the garden, and eventually the hand was amputated. The specimen is still preserved in the museum at St. Bartholomew's Hospital (Specimen No. Z268).

Following Pott's description in 1775 the next account of chimney sweepers' cancer was by his grandson, Henry Earle (1823). Earle mentions the case of the gardener's hand related by his father in Pott's Chirurgical works, and states that chimney sweepers' cancer rarely attacks persons under the age of 30 , the larger proportion of cases that he had seen having been between 30 and 40, with three cáses between 20 and 30 , and only one at the age of puberty. In this communication Earle relates two cases, one, whose grandfather, father, and brother had all died from the same disease.

An Act of Parliament was passed in 1840 to provide that after July 1, 1842, no sweep under the age of 21 years should climb a chimney, and that no apprentice of less than 16 years of age should be taken. This, however, was not enforced until 1875 when it was decreed that chimney sweepers must be licensed, and that licences would be withdrawn for offences against previous Acts.

Our next contributor to the subject of cancer of the scrotum as recorded at St. Bartholomew's Hospital was Sir Henry T. Butlin (1845-1912). In 1889 he stated that there had been 39 patients under treatment in the hospital between 1869 and 1888, an average of about two per annum, the large majority of these patients being chimney sweepers. Writing a few years later Butlin (1892) stated that at that time there was no decline in the number of cases, and that of the above-mentioned cases 29 were employed as sweeps, and only four or five were in employment unconnected with soot. Butlin carefully investigated the incidence of chimney sweepers' cancer abroad, and found it to be extremely rare outside England. It has been suggested that the structural peculiarities of English chimneys, the type of coal used, the lack of efficient protective clothing, and disregard of personal hygiene all contributed to this peculiarity.

Henry (1946) in his comprehensive study of cancer of the scrotum with particular reference to occupations, gives a chronological list of the literature of the subject. Hueper (1942) gives extensive references to the literature of scrotal cancer in the section devoted to soot. He states that at St. Bartholomew's Hospital, London, between 1910 and 1912, 23 out of 107 deaths of chimney sweepers were due to cancer of the scrotum, and Kennaway (1925) suggests that there was no evidence to suggest that chimney sweepers' cancer had become less frequent during 1910-1923, giving the following figures for England and Wales: 1910-12, 16; 1913-14, 7; 1921-22, 10; 1923, 4. Kennaway and Kennaway (1937) also state that from 1911 to 1935 , out of a population of 5,274 chimney sweepers there were 100 deaths from cancer of the scrotum, a much higher incidence than in other occupations.

However, at St. Bartholomew's Hospital during the years 1948-52 there was only one case noted as chimney sweepers' cancer in about 5,000 cancer cases, which suggests that alternative methods of heating, improved hygiene in the trade of chimney sweepers, and improved methods of cleaning chimneys are leading to the eradication of this disease.

We are indebted to Sir Ernest Kennaway and Dr. S. A. Henry for encouragement and advice during the preparation of this paper.

\section{REFERENCES}

Butlin, Henry T. (1889). St. Bart's Hosp. Rep., 25, 193. Earle, H. (1823). Med. -C Chir. Trans., 12, 296.

Henry, S. A. (1946). Cancer of the Scrotum in Relation to Occupation. Oxford University Press, London.

Horder, Thomas J. (1894). St. Bart's Hosp. Rep., 30, 163.

Hueper, W. C. (1942). Occupational Tumors and Allied Diseases. Thomas, Springfield, III.

Kennaway, E. L. (1925). J' industr. Hyg., 7, 69.

, and Kennaway, N. M. (1937); Acta Un. int. Cancr, 2, 101. 